\title{
The Impact of Affinity on World Economic Integration: The Case of Japanese Foreign Direct Investment
}

\author{
Hyoung-kyu Chey \\ National Graduate Institute for Policy Studies (GRIPS)
}

June 2011

This is the preprint version of the following article: Hyoung-kyu Chey. (2012). "The impact of affinity on world economic integration: The case of Japanese foreign direct investment," Japan and the World Economy, volume 24, issue 1, pages 57-63, which has been published in final form at https://doi.org/10.1016/i.japwor.2012.01.001. 


\begin{abstract}
This paper finds that a country's affinity with a foreign country has a positive effect on foreign direct investment flows from it to that country, by analyzing Japanese foreign direct investment outflows during the period of 1995 to 2009. A rise in affinity between countries is thought to enhance their mutual trust and as a result lower the transaction costs of economic activities between them, thereby helping to promote bilateral foreign direct investment flows. These findings imply that a rise in affinity among countries is likely to facilitate international economic integration.
\end{abstract}

Keywords: affinity; economic integration; foreign direct investment; globalization; multinational corporations

JEL classification: F2 


\section{Introduction}

International economic integration, or globalization, has intensified greatly in several ways over the past decades. One increasingly salient dimension of this trend is foreign direct investment (FDI). ${ }^{1}$ The total volume of global FDI inflows has increased rapidly since the late 1980s especially—growing about 38 times from 55.8 billion dollars in 1985 to 2.1 trillion dollars in 2007. FDI is widely, if not universally, assessed as providing significant economic benefits for the host countries, contributing to their growth through provision of external financing, job creation, technology transfer, etc. A number of countries have adopted diverse policies to attract more FDI, as an important economic development strategy.

What factors determine the locations of FDI? To which countries do more FDI flow? This research addresses these questions as a way of identifying factors affecting the degree of world economic integration. The existing literature on FDI presents diverse factors as significant determinants of FDI location. Economic conditions in the host countries have been traditionally pointed to as the main factors affecting FDI flows, among them those related to market potential, production costs, business operation environment, etc. Host country political conditions have also attracted growing attention. Although this is at times

\footnotetext{
${ }^{1}$ A common definition of FDI is "an investment involving a long-term relationship and reflecting a lasting interest and control by a resident entity in one economy (foreign direct investor or parent enterprise) in an enterprise resident in an economy other than that of the foreign direct investor (FDI enterprise or affiliate enterprise or foreign affiliate)" (UNCTAD, 2008, p. 249).
} 
controversial, a good number of studies argue that certain specific political characteristics, such as political stability and political regime type, have significant effects on FDI inflows.

In contrast to such studies, this paper seeks to demonstrate that psychological factors also affect FDI flows substantially. In particular, it argues that one country's affinity (sense of closeness or the positive sentiment of its population) with another country positively impacts its FDI flows to that country, by analyzing the influence of Japanese affinity with foreign countries on Japanese FDI outflows during the years from 1995 to 2009. The mechanism through which affinity affects FDI flows is supposed to be as follows: a rise in one party's affinity with a potential business partner is likely to increase its trust in that partner; this increase in trust is likely to then lower transaction costs during economic activities between the two parties, in turn boosting the volume of those activities. The findings suggest that increases in affinity among countries may facilitate world economic integration, or economic globalization.

This paper is organized as follows. It first briefly reviews the literature on the determinants of FDI location, and then develops its main argument regarding the impact of affinity on FDI flows. It next discusses the research design of its empirical analysis, after which it reviews the results of this analysis. In the final section, it discusses the implications and the limitations of its findings.

\section{Affinity, trust, and transaction costs}


Existing research on FDI has presented diverse factors as important determinants of FDI location. First of all, economic conditions in host countries are generally regarded as salient factors affecting FDI inflows to them. ${ }^{2}$ Among these conditions, market-related factors, especially market size, are most frequently indicated as important (e.g., [Gastanaga et al., 1998], [Lipsey, 1999] and [Schneider and Frey, 1985]). Other host country economic conditions, such as labor costs, tax rates, openness, trade barriers, etc., have been widely studied as factors affecting FDI flows as well, although empirical findings as to their effects are quite inconclusive (e.g., [Asiedu, 2002], [Billington, 1999], [Blonigen, 2002], [Culem, 1988], [Devereux and Freeman, 2007], [Edwards, 1990], [Ekholm et al., 2003], [Mudambi, 1995], [Lunn, 1980], [Tsai, 1994] and [Wheeler and Mody, 1992]). Some political factors have also been analyzed by several studies, mainly in the international political economy field. Political instability is one such variable that many have traditionally addressed (e.g., [Büthe and Milner, 2008], [Li and Resnick, 2003], [Trevino et al., 2002] and [Tuman and Emmert, 2004]). A growing number of studies have paid attention to the effects of political regime type on FDI inflows as well, presenting conflicting theories and empirical findings on the effects of democratic and authoritarian institutions on FDI inflows (e.g., [Büthe and Milner, 2008], [Feng, 2001], [Jakobsen and Soysa, 2006], [Jensen, 2003], [Jessop, 1999], [Li and Resnick, 2003], [O’Donnell, 1978], [Oneal, 1994] and [Resnick, 2001]).

There could conceivably be other important FDI location determinants, however. This

\footnotetext{
${ }^{2}$ For a good review of the literature on economic determinants of FDI location, see Blonigen (2005). For a typical economic analysis of FDI also see Dunning $(1977,1979,1980)$, who has introduced the "eclectic" or "OLI" paradigm in analyzing FDI.
} 
paper focuses on a psychological one, affinity, arguing that a country's affinity with a foreign country positively affects its FDI flows to that country. And there are in fact a group of studies, especially in the international business literature, that address the impact of psychological factors on FDI flows (e.g., [Ghemawat, 2001], [Habib and Zurawicki, 2002], [Johanson and Vahlne, 1977, 1990], [Johanson and Wiedersheim-Paul, 1975], [Kogut and Harbir, 1988], [Li and Guisinger, 1992] and [Loree and Guisinger, 1995]). ${ }^{3}$ They examine "psychic distance" (the perceived distance between the home and a foreign country, stemming from differences in culture, economy, politics, etc), or focus more narrowly on "cultural distance" only. They argue that psychic or cultural distance between the home and a foreign country has a negative impact on FDI flows between them. These studies tend not to directly address psychological distance between the home and a foreign country per se, however, but instead indirectly consider their differences in culture, economic development, political system, etc. Such differences may affect psychological distance, but whether they necessarily always do so seems debatable. In contrast to such studies, therefore, this paper deals directly with the impact of psychological distance on FDI flows, by explicitly addressing one country's affinity with foreign countries.

Affinity between two countries is thought to affect FDI flows between them through the following mechanism. Firstly, given that social relations are primarily accountable for the generation of trust in economic life (Granovetter, 1985), and that affinity strengthens social relations by fostering a sense of closeness (Moreland and Beach, 1992), it may be reasonable to expect a positive relationship between one's affinity with a counterparty and

\footnotetext{
${ }^{3}$ For a review of this literature see Kirkman et al. (2006).
} 
one's trust in her or him. When one's affinity with others increases, one's trust in them is therefore also likely to grow. Conversely, when one's feeling of closeness to others declines, trust in them will likely follow. ${ }^{4}$ Trust in economic relationships is a valuable asset, that lowers transaction costs in a number of ways. For example, where high trust between firms exists they will be confident of a fair division of the payoffs on their cooperative business activities, and feel less need for heavy investment in ex ante bargaining. Their negotiations may in addition be more efficient, owing to their confidence that information provided by their partners is not misrepresented. Ex ante contracting costs will decline as a result. Trust may reduce ex post contracting costs as well, as firms' trust in their partners will lead them to devote fewer resources to contract monitoring and enforcement, or to ex post bargaining and haggling over problems emerging in the course of the actual transacting (Boersma, et al., 2003; Dyer and Chu, 2003). Given that transaction costs have a great impact on economic efficiency, their lowering can affect economic activities significantly (North, 1990). ${ }^{5}$ Such functions of affinity in business activities may be of particular significance for FDI, given its objective of obtaining lasting interest, implying therewith a long-term relationship between the investor and the host country.

There are indeed statistical studies whose findings support such a positive relationship

\footnotetext{
4 The formation of affinity may be influenced by diverse factors, such as cultural closeness, political ideology, economic reputation, etc. However, study of the sources of affinity is beyond the coverage of this paper, which focuses only on the effects of affinity on economic behavior, in particular on FDI flows.

${ }^{5}$ North (1990) estimates that as much as 35 to 40 percent of the costs associated with economic activities may be accounted for by transaction costs.
} 
between trust and low transaction costs. Butter and Mosch (2003), for example, show that trust between trading partners significantly enhances trade by lowering transaction costs. Guiso et al. (2004) meanwhile demonstrate that increased trust of importers toward exporters boosts exports in European countries, while Dyer and Chu (2003) find an inverse relationship between trust and transaction costs in their analysis of supplier-automaker exchange relationships in the United States, Japan and South Korea. There is in addition empirical research finding a significant positive relationship between affinity and business activities. Noland (2004), for instance, shows a significant positive impact of the attitude of the US public toward foreign countries on the volume of US trade.

I thus argue that a high level of affinity between two countries is likely to promote economic activities between them, through the channel of an increase in mutual trust and resulting decrease in the transaction costs of economic activities between them. This argument yields the following testable hypothesis regarding FDI flows, all other things being equal:

Hypothesis: The higher a country's affinity with a foreign country, the more likely its FDI is to flow to that country.

\section{Data and Methodology}

To test this hypothesis, I conduct a statistical analysis of Japanese FDI outflows to twelve 
countries during the period of 1995 to 2009. The countries are Australia, China, France, Germany, India, Indonesia, New Zealand, Russia, South Korea, Thailand, the United Kingdom, and the United States. They were selected based on the availability of data concerning Japanese affinity with them, while the period of observation was chosen in consideration of Japanese FDI data continuity. ${ }^{6}$

\section{Dependent variable}

The dependent variable is the volume of net Japanese FDI outflow to a country on a balance of payments basis, measured in millions of US dollars. ${ }^{7}$ This measure is compatible with the key research question of this study, which is whether a country's affinity with another country promotes FDI flows from it to that country. Some studies on the determinants of FDI location use the ratio of FDI inflows to the host country's GDP as their dependent variable (e.g., [Büthe and Milner, 2008] and [Tuman and Emmert, 2004]). Their reason for transforming the variable in this way is to measure the relative importance of the FDI inflow to the host country's economy (Li and Resnick, 2003). This may not be consistent with the research question of this study, however, which concerns the level of

\footnotetext{
${ }^{6}$ The Japanese FDI data used in this study does not have strict continuity before 1995, due to changes in the dollar conversion method used and the definition of FDI.

${ }^{7}$ FDI figures were first released in Japanese yen and then converted into US dollars using the Bank of Japan average inter-bank rates.
} 
Japanese FDI outflows per se. ${ }^{8}$

The variable is adjusted to take into account inflation by using the consumer price index, and is logged to deal with its skewed distribution. Data is provided by the Japan External Trade Organization, based upon Japanese Ministry of Finance Balance of Payments Statistics and Bank of Japan foreign exchange rates. In the statistical analysis, the dependent variable is labeled as JAPANESE FDI.

\section{Explanatory variable}

The explanatory variable that this research focuses on is the level of Japanese affinity with a foreign country. To measure this, I use as a proxy the percentage of respondents expressing affinity with the country in the Japanese government's annual public opinion survey on Japan's foreign relations (Kaikou-ni Kansuru Seron-chyousa). ${ }^{9}$

The survey cited has been conducted every October since 1977, with its target respondents people over age 20. The size of its sample has been 3,000, and from 1999 to 2009 the response rate ranged from about 60 to 70 percent. The survey sampling method is two-staged stratified random sampling. In the questionnaire, the question as to affinity with a foreign country has five possible responses: (i) feel affinity; (ii) if must choose, feel

\footnotetext{
${ }^{8}$ In analyzing FDI inflows, Li and Resnick (2003) and Oneal (1994) also use the level of FDI inflows as their dependent variables, rather than such a transformed variable.

${ }^{9}$ The results of the survey are available on the website of the Cabinet Office of Japan (http://www.cao.go.jp), in Japanese only.
} 
affinity; (iii) don’t know; (iv) if must choose, don't feel affinity; and (v) don't feel affinity. The percentage share in total respondents of the number checking either of the first two choices is reported as the percentage feeling affinity with the country.

The countries that the survey covers individually are limited to China, South Korea, Russia, and the United States. It does cover Australia and New Zealand as well, but does not separately distinguish between affinities with the two countries, asking about only affinity with "Australia and New Zealand." I thus allocate identically to both countries the reported percentage of those expressing affinity with "Australia and New Zealand." Meanwhile, the survey also examines affinity with groups of countries in different regions in an aggregate sense, that is, affinity with "Southeast Asian countries," "Southwest Asian countries," "Western European countries," etc. I allocate the percentage of those expressing affinity with "Southeast Asian countries" to Thailand and Indonesia, as they are explicitly cited as examples of Southeast Asian countries on the survey questionnaire. For the same reason, I adopt the percentage of those who show affinity with "Southwest Asian countries" as the measure of the Japanese affinity with India, and that of those expressing affinity with "Western European countries" as indicating their affinity equally with France, Germany and the United Kingdom. ${ }^{10}$

\footnotetext{
${ }^{10}$ Since 2008, the survey has replaced the question of affinity with "Southwest Asian countries" with that of affinity with "India," and that of affinity with "Western European countries" with that of affinity with "European countries," citing the United Kingdom, France and Poland as examples. For consistency of data, I allocate the values of affinity with "European countries" for 2008 and 2009 to the United Kingdom, France and Germany.
} 
This measurement of affinity may not be the best one. However, the fact that the questionnaire does not specify individual countries in those regions per se may suggest that Japanese affinity with a country within one region may not be substantially different from that with other regional countries. The affinity measure adopted here does not appear a serious problem, therefore, while it has the advantage of increasing the number of observations.

The explanatory variable is labeled as AFFINITY, and is lagged by one year, in consideration of the time lag between an investment decision and the actual investment. I expect that the higher the Japanese affinity with a country is, the more Japanese FDI outflows into that country there will be. AFFINITY is accordingly expected to have a positive impact on JAPANESE FDI.

Meanwhile, it is possible that a change in affinity, rather than its level, is what affects Japanese FDI outflows. This possibility is unlikely to be great, though, since even when Japanese affinity with a foreign country rises slightly the affinity level can still be low. I do test this possibility in statistical analysis as well, however.

\section{Control variables}

The control variables include five economic variables - market size, labor cost, corporate tax rate, openness, and trade barriers - and two political variables — democracy and political stability. I select these variables because they are the ones frequently considered important FDI location determinants in the literature, as mentioned earlier. 


\section{Economic variables}

MARKET SIZE. The host country's GDP in constant (2000) US dollars is used to measure its market size. The variable is logged, with a one-year lag. Data is from the World Bank's World Development Indicators. Given that the literature on FDI flows generally finds a positive relationship between a country's market size and the volume of FDI inflows to it, MARKET SIZE is expected to affect JAPANESE FDI positively.

LABOR COST. Real manufacturing wages are used as a proxy measure for labor costs. I estimate real annual wages converted into US dollars, using data on wages in local currencies obtained mainly from the United Nations' Statistical Yearbook. The variable is logged, with a one-year lag. Considering that low wages may increase the profitability of FDI, I expect LABOR COST to show a negative relationship with JAPANESE FDI.

CORPORATE TAX. The variable is the corporate tax rate in the sample country, lagged by one year. Data is from KPMG's Corporate and Indirect Tax Rate Survey 2010. Given that a high corporate tax rate may lower an FDI firm's income, CORPORATE TAX RATE is expected to affect JAPANESE FDI negatively.

OPENNESS. For the measurement of host country openness, I use the ratio of its trade to GDP from the World Bank's World Development Indicators, lagged by one year. As export- 
oriented FDI seems likely to prefer a more open economy, I expect a positive relationship between OPENESS and JAPANESE FDI.

TRADE BARRIERS. In measuring the degree of trade barriers, I use average Most Favored Nation-applied tariff rates as a proxy measure, lagged by one year. Data is from the World Bank's Data on Trade and Import Barriers. Considering that FDI may be used as a means of overcoming trade barriers, TRADE BARRIERS is expected to have a positive impact On JAPANESE FDI.

\section{Political variables}

DEMOCRACY. As the measure of a country's level of democracy, I use the Revised Combined Polity Score (POLITY2) in the Polity IV dataset, widely used in political science research. The polity score is computed by subtracting the score for autocracy from that for democracy, and ranges from -10 (strong autocratic) to +10 (strong democratic). I lag the variable by one year. The literature contains conflicting expectations as to the impact of democracy on FDI inflows, with some claiming it to be positive and some the opposite. Empirical testing of the effect of DEMOCRACY on JAPANESE FDI is therefore done without expectation.

POLITICAL STABILITY. To measure political stability, I use the Cingranelli-Richards (CIRI) Human Rights Dataset. Although this dataset is in principle set up to provide 
information on government respect for internationally recognized human rights, it includes an indicator that may be used as a proxy measure of countries' political stability. This is the Physical Integrity Rights Index, an additive index constructed from indicators of torture, extrajudicial killing, political imprisonment and disappearance. It ranges from 0 (no government respect for these four rights) to 8 (full government respect for them). ${ }^{11}$ The variable is lagged by one year. Empirical studies of the relationship between political stability and FDI flows have presented mixed results. It appears theoretically more plausible to expect political stability to attract more FDI inflows, however, and I thus anticipate a positive relationship between POLITICAL STABILITY and JAPANESE FDI.

\section{Estimation method}

The data has a pooled time-series cross-section (TSCS) structure, characterized by containing repeated observations on fixed units over a relatively long period of time. Due to their temporal and spatial properties, TSCS data often show panel heteroscedasticity in the errors, contemporaneous correlation of errors, and autocorrelation of errors (Beck and Katz, 1995). ${ }^{12}$ To deal with these problems, I run a Prais-Winsten regression adopting a common

\footnotetext{
11 The World Bank publishes data on Political Stability and the Absence of Violence/Terrorism in its World Governance Indicators, but consecutive annual data is available only from 2002. The correlation between this data and the CIRI Human Rights Dataset is meanwhile very high (0.90), and this study's use of the CIRI Human Rights Dataset as a proxy for political stability thus appears a reasonable choice.

12 Panel heteroscedasticity means that the variances of the error process differ across units. Contemporaneous
} 
first-order autoregressive (AR(1)) process with the use of panel-corrected standard errors (PCSE), as recommended by Beck and Katz (1995). PCSE addresses the problems of heteroskedasticity and contemporaneous correlation in the error terms, while the PraisWinsten regression takes into account the AR(1) process. The regression equation is formed as follows: $:^{13}$

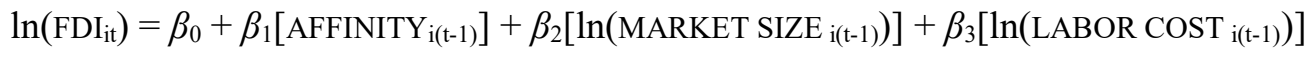

$$
\begin{aligned}
& +\beta_{4}\left[\text { CORPORATE TAX }_{\mathrm{i}(t-1)]}\right]+\beta_{5}\left[\text { OPENNESS }_{\mathrm{i}(\mathrm{t}-1)}\right]+\beta_{6}\left[\text { TRADE BARRIERS }_{\mathrm{i}(\mathrm{t}-1)]}\right] \\
& +\beta_{7}\left[\text { DEMOCRACY }_{\mathrm{it}(-1)]}\right]+\beta_{8}\left[\text { POLITICAL STABILITY }_{\mathrm{i}(\mathrm{t}-1)}\right]+\varepsilon_{\mathrm{it}},
\end{aligned}
$$

where subscripts $i$ and $t$ denote the FDI target country and the year, respectively.

\section{Findings}

Summary statistics for the variables are reported in Table 1. Multicollinearity among AFFINITY and the control variables is tested by examining their variance inflation factor

correlation of errors means that the errors for one unit are correlated with the errors for other units.

Autocorrelation of errors means that the errors for a given country are correlated with previous errors for that country (Beck, 2001).

13 The estimation uses STATA 11. 
(VIF) values. The highest VIF value is to found to be 8.41 (LABOR COST) and the mean VIF 3.44, suggesting that problems of multicollinearity among the variables are not serious. ${ }^{14}$

[Insert Table 1 here]

To estimate the impact of affinity on Japanese FDI location, I specify a variety of models. Model 1 is this study's standard model, while Model 2 excludes the data for the United States and Model 3 that for China. I do this because these two countries absorbed the dominant shares of total Japanese FDI outflows, potentially creating problems for test result reliability. Model 4 meanwhile limits the observation period to the 2000 s, given that Japanese FDI outflows may have been abnormal during the late 1990s due to the 1997 Asian financial crisis. Model 5, finally, uses as AFFINTIY the annual change in Japanese affinity with a foreign country, calculated as the percentage of respondents expressing affinity with the country in that year minus the same percentage the previous year, to test whether Japanese FDI outflows to foreign countries are affected by the changes in, rather than the levels of, Japanese affinity with them.

Table 2 presents the statistical results from the five model specifications. As seen from the data, all models except Model 4 explain more than 90 percent of the variations in Japanese FDI outflows.

\section{[Insert Table 2 here]}

\footnotetext{
14 VIF values larger than 10 are generally regarded as showing the presence of multicollinearity.
} 
AFFINITY is statistically significant at the 1 percent level and positive, as expected, in Model 1. A one unit change in AFFINITY in this model causes about a 4.5 percent change in JAPANESE FDI, with the control variables all held constant. The higher the level of Japanese affinity with a foreign country, the more Japanese FDI flew toward that country. The positive relationship between the two variables remained significant through Models 2 to 4, as well. Meanwhile, the results of Model 5 estimation show no significant effect of a change in Japanese affinity with a country on Japanese FDI outflows toward it. All of these statistical results offer strong support for the hypothesis.

Meanwhile, MARKET SIZE is positive as expected and statistically significant in all five models, implying that a larger market size is likely to attract more FDI inflows. LABOR COST shows the expected negative effect on FDI flows, although its statistical significance is limited to two of the five models. CORPORATE TAX is also negative as expected and statistically significant in all models except Model 5, suggesting that a higher corporate tax rate is more likely to be an obstacle to FDI inflows. TRADE BARRIERS is positive as anticipated in all except Model 4, but statistically significant only in Model 3. OPENNESS shows the expected positive result, but with statistical significance only in two of the five models. DEMOCRACY is negative and statistically significant in all models but Model 4, supporting the claim that FDI favors authoritarian over democratic regimes. POLITICAL STABILITY meanwhile shows no statistical significance in any of the five models. 


\section{Robustness Checks}

To probe the soundness of the findings, I conduct a series of robustness checks of the Model 1 estimation results, using alternative estimation methods. Model 6 adopts a country-specific AR(1) process, running a Prais-Winsten regression with the use of PCSE. According to Beck and Katz (1995), adoption of a common rather than a country-specific AR(1) process is a superior method, as it is likely to lead to the standard errors estimating variability more accurately. It may nevertheless also be worthwhile evaluating robustness of the Model 1 results using the alternative assumption. Meanwhile, instead of Prais-Winsten regression adopting PCSE, Models 7 and 8 use the Parks method (see Parks, 1967), that is, feasible generalized least squares (an alternative approach for TSCS analysis) —adopting a common and a country-specific AR(1) process, respectively.

Table 3 reports the estimation results for the three models, which are to a great extent consistent with those in Table 2. In terms of hypothesis testing for affinity and FDI flows, AFFINITY shows a significant positive effect on JAPANESE FDI in all three models. For control variables, MARKET SIZE, CORPORATE TAX, and DEMOCRACY show significant negative effects on JAPANESE FDI in all models as well. LABOR COST is also negative and statistically significant in two of the three models. Meanwhile, OPENNESS, TRADE BARRIERS and POLITICAL STABILITY show no significant effects on JAPANESE FDI.

[Insert Table 3 here] 


\section{Conclusion}

FDI is an important element in world economic integration, or economic globalization. Accordingly, study of the determinants of FDI location can provide helpful insight for understanding the factors strengthening world economic integration. In this context, this research has addressed the determinants of FDI location, highlighting the fact that the psychological factor of affinity has a significant positive relationship with FDI flows, by empirically analyzing Japanese FDI outflows.

The findings imply that a rise in a country's "soft power," which is likely to be closely linked to foreigners' affinity with that country, may help it to engage in cooperative economic activities with other countries more easily, intensifying its economic integration with them. ${ }^{15}$ It may also be reasonable to expect that a friendly and strong political relationship between two countries will boost their mutual affinity, and accordingly that development of close ties between countries in the political sphere is likely to contribute to their economic integration. This reasoning may be extensively applied to regional integration, emphasizing the importance of regional institutions that can increase political coherence among member countries for economic integration.

In closing, two limitations of this research should be mentioned. One is that it does not provide an empirical analysis of the channel through which affinity influences FDI flows,

15 Soft power is the ability to get others to do what one wants through attraction rather than use of coercion or payment (Nye, 2004). 
although showing a positive relationship between the two variables per se. As discussed earlier, however, there are empirical studies supporting this paper's suggestion as to the channel through which affinity affects FDI flows. This study's other limitation is that it examines the Japanese FDI case only, although this is mainly related to the availability of data on affinity. ${ }^{16}$ Note in addition that, as mentioned earlier, Noland (2005) also finds US affinity with foreign countries to have a positive effect on US trade volume, implying that the significant effect of affinity on economic activities may not be a phenomenon unique to the Japanese alone.

\section{References}

Asiedu, E., 2002. On the Determinants of Foreign Direct Investment to Developing Countries: Is Africa Different? World Development 30 (1), 107-119.

Beck, N., 2001. Time-Series-Cross-Section Data: What Have We Learnt in the Past Few Years? Annual Review of Political Science 4, 271-293.

Beck, N., Katz, J. N., 1995. What to Do (and Not to Do) with Time-Series Cross-Section Data. The American Political Science Review 89 (3), 634-647.

\footnotetext{
16 Noland (2005) uses the survey data on US affinity with foreign countries in his analysis of affinity and international trade. However, the method of measuring affinity in the US survey differs from that in the Japanese survey used in this paper; in the US survey, respondents are asked to rate their affinity with foreign countries on a scale of 0 to 100 , with higher figures indicating greater affinity.
} 
Billington, N., 1999. The Location of Foreign Direct Investment: An Empirical Analysis. Applied Economics 31 (1), 65-76.

Blonigen, B. A., 2002. Tariff-Jumping Antidumping Duties. Journal of International Economics 57 (1), 31-50. 2005. A Review of the Empirical Literature on FDI Determinants. NBER Working Paper No. 11299, Cambridge, MA: National Bureau of Economic Research.

Boersma, M. F., Buckley, P. J., Ghauri, P. N., 2003. Trust in International Joint Venture Relationships. Journal of Business Research 56 (12), 1031-1042.

Büthe, T., Milner, H. V., 2008. The Politics of Foreign Direct Investment into Developing Countries: Increasing FDI through International Trade Agreements? American Journal of Political Science 52 (4), 741-762.

Butter, F. A. G. den., Mosch, R. H. J., 2003. Trade, Trust and Transaction Costs. Tinbergen Institute Discussion Paper TI 2003-082/3, Amsterdam: Tinbergen Institute Rotterdam.

Culem, C. G., 1988. The Locational Determinants of Direct Investments among Industrialized Countries. European Economic Review 32 (4), 885-904.

Devereux, M. B., Shi, K., Xu, J., 2007. Global Monetary Policy under a Dollar Standard. Journal of International Economics 71 (1), 113-132.

Dunning, J. H., 1977. Trade, Location of Economic Activity and the Multinational Enterprise: A Search for an Eclectic Approach. In: Ohlin, B., Hesselborn, P.-O., Wijkman, P. M. (Eds.). The International Allocation of Economic Activity: Proceedings of a Nobel Symposium Held at Stockholm, London: Macmillan. 
1979. Explaining Changing Patterns of International Production: In Defence of the Eclectic Theory. Oxford Bulletin of Economics and Statistics 41 (4), 269-295. 1980. Toward an Eclectic Theory of International Production: Some Empirical Tests. Journal of International Business Studies 11 (1), 9-31.

Dyer, J. H., Chu, W., 2003. The Role of Trustworthiness in Reducing Transaction Costs and Improving Performance: Empirical Evidence from the United States, Japan, and Korea. Organization Science 14 (1), 57-68.

Edwards, S., 1990. Capital Flows, Foreign Direct Investment, and Debt-Equity Swaps in Developing Countries. NBER Working Paper No. 3497, Cambridge, MA: National Bureau of Economic Research.

Ekholm, K., Forslid, R., Markusen, J. R., 2003. Export-Platform Foreign Direct Investment. NBER Working Paper No. 9517, Cambridge, MA: National Bureau of Economic Research.

Feng, Y., 2001. Political Freedom, Political Instability, and Policy Uncertainty: A Study of Political Institutions and Private Investment in Developing Countries. International Studies Quarterly 45 (2), 271-294.

Gastanaga, V. M., Nugent, J. B., Pashamova, B., 1998. Host Country Reforms and FDI Inflows: How Much Difference Do They Make? World Development 26 (7), 12991314.

Ghemawat, P., 2001. Distance Still Matters: The Hard Reality of Global Expansion. Harvard Business Review 79 (8), 137-147.

Granovetter, M., 1985. Economic Action and Social Structure: The Problem of 
Embeddedness. American Journal of Sociology 91 (3), 481-510.

Guiso, L., Sapienza, P., Zingales, L., 2004. Cultural Biases in Economic Exchange. NBER Working Paper No. 11005, Cambridge, MA: National Bureau of Economic Research.

Habib, M., Zurawicki, L., 2002. Corruption and Foreign Direct Investment. Journal of International Business Studies 33 (2), 291-307.

Jakobsen, J., Soysa, I. D., 2006. Do Foreign Investors Punish Democracy? Theory and Empirics, 1984-2001. Kyklos 59 (3), 383-410.

Jensen, N. M., 2003. Democratic Governance and Multinational Corporations: Political Regimes and Inflows of Foreign Direct Investment. International Organization 57 (3), 587-616.

Jessup, D., 1999. Dollars and Democracy. Available from <http://www.newecon.org/DDintro.html > (accessed on 28 October 2008).

Johanson, J., Vahlne, J.-E., 1977. The Internationalization Process of the Firm: A Model of Knowledge Development and Increasing Foreign Market Commitment. Journal of International Business Studies 8 (1), 23-32. 1990. The Mechanism of Internationalization. International Marketing Review 7 (4), $11-24$

Johanson, J., Wiedersheim-Paul, F., 1975. The Internationalization of the Firm: Four Swedish Cases. Journal of Management Studies 8 (1), 305-322.

Kirkman, B. L., Lowe, K. B., Gibson, C. B., 2006. A Quarter Century of Culture's Consequences: A Review of Empirical Research Incorporating Hofstede's Cultural 
Values Framework. Journal of International Business Studies 37 (3), 285-320.

Kogut, B., Singh, H., 1988. The Effect of National Culture on the Choice of Entry Mode. Journal of International Business Studies 19 (3), 411-432.

Li, J., Guisinger, S., 1992. The Globalization of Service Multinationals in the "Triad" Regions: Japan, Western Europe and North America. Journal of International Business Studies 23 (4), 675-696.

Li, Q., Resnick, A., 2003. Reversal of Fortunes: Democratic Institutions and Foreign Direct Investment Inflows to Developing Countries. International Organization 57 (1), $175-211$.

Lipsey, R. E., 1999. The Location and Characteristics of U.S. Affiliates in Asia. NBER Working Paper No. 6876, Cambridge, MA: National Bureau of Economic Research.

Loree, D. W., Guisinger, S. E., 1995. Policy and Non-Policy Determinants of U.S. Equity Foreign Direct Investment. Journal of International Business Studies 26 (2), 281299.

Lunn, J., 1980. Determinants of U.S. Direct Investment in the E.E.C. European Economic Review 13 (1), 93-101.

Moreland, R. L., Beach, S. R., 1992. Exposure Effects in the Classroom: The Development of Affinity among Students. Journal of Experimental Social Psychology 28 (3), 255276.

Mudambi, R., 1995. The MNE Investment Location Decision: Some Empirical Evidence. Managerial and Decision Economics 16 (3), 249-257.

Noland, M., 2004. Popular Attitudes, Globalization, and Risk. Working Paper WP 04-2, 
Washington, DC: Institute for International Economics. 2005. Affinity and International Trade. Working Paper WP 05-3, Washington, DC: Institute for International Economics.

North, D. C., 1990. Institutions, Institutional Change and Economic Performance, Cambridge: Cambridge University Press.

Nye, J. S. J., 2004. Soft Power: The Means to Success in World Politics, New York: Public Affairs.

O'Donnell, G., 1978. Reflections on the Patterns of Change in the BureaucraticAuthoritarian State. Latin American Research Review 13 (1), 3-38.

Oneal, J. R., 1994. The Affinity of Foreign Investors for Authoritarian Regimes. Political Research Quarterly 47 (3), 565-588.

Parks, R., 1967. Efficient Estimation of a System of Regression Equations When Disturbances Are Both Serially and Contemporaneously Correlated. Journal of the American Statistical Association 62 (318), 500-509.

Resnick, A. L., 2001. Investors, Turbulence, and Transition: Democratic Transition and Foreign Direct Investment in Nineteen Developing Countries. International Interactions 27 (4), 381-398.

Schneider, F., Frey, B. S., 1985. Economic and Political Determinants of Foreign Direct Investment. World Development 13 (2), 161-175.

Trevino, L. J., Daniels, J. D., Arbeláez, H., 2002. Market Reform and FDI in Latin America: An Empirical Investigation. Transnational Corporations 11 (1), 29-48.

Tsai, P.-L., 1994. Determinants of Foreign Direct Investment and Its Impact on Economic 
Growth. Journal of Economic Development 19 (1), 137-163.

Tuman, J. P., Emmert, C. F., 2004. The Political Economy of U.S. Foreign Direct

Investment in Latin America: A Reappraisal. Latin American Research Review 39 (3), 9-28.

UNCTAD, 2008. World Investment Report 2008, New York and Geneva: United Nations.

Wheeler, D., Mody, A., 1992. International Investment Location Decisions: The Case of US Firms. Journal of International Economics 33 (1-2), 57-76. 
Table 1. Descriptive Statistics

\begin{tabular}{llllll}
\hline Variables & Observations & Mean & Standard dev. & Minimum & Maximum \\
\hline JAPANESE FDI & 115 & 20.8633 & 1.3995 & 17.0516 & 24.4251 \\
AFFINITY & 115 & 49.0557 & 14.7658 & 13 & 77.6 \\
MARKET SIZE & 115 & 27.4440 & 1.3263 & 24.5773 & 30.0725 \\
LABOR COST & 115 & 9.0575 & 1.6335 & 5.7851 & 10.8921 \\
CORPORATE TAX & 115 & 33.9867 & 6.0478 & 24 & 59 \\
OPENNESS & 115 & 54.7304 & 20.6590 & 23 & 125 \\
TRADE BARRIERS & 115 & 8.9713 & 8.8254 & 1.4 & 41 \\
DEMOCRACY & 115 & 6.5826 & 5.8279 & -7 & 10 \\
POLITICAL STABILITY & 115 & 4.5043 & 2.6930 & 0 & 8 \\
\hline
\end{tabular}


Table 2. Determinants of Japanese FDI outflows, 1995-2009

\begin{tabular}{|c|c|c|c|c|c|}
\hline & Model 1 & Model 2 & Model 3 & Model 4 & Model 5 \\
\hline \multirow[t]{2}{*}{ AFFINITY } & $0.0454 * * *$ & $0.0303 * *$ & $0.0646^{* * *}$ & $0.0594 * * *$ & 0.0082 \\
\hline & $(0.0098)$ & $(0.0118)$ & $(0.0081)$ & $(0.0096)$ & $(0.0163)$ \\
\hline \multirow[t]{2}{*}{ MARKET SIZE } & $0.6662 * * *$ & $0.5146 * * *$ & $0.7685 * * *$ & $0.8361 * * *$ & $0.6841 * * *$ \\
\hline & $(0.0932)$ & $(0.1169)$ & $(0.0826)$ & $(0.0851)$ & $(0.1146)$ \\
\hline \multirow[t]{2}{*}{ LABOR COST } & -0.2412 & -0.1884 & $-0.4680 * * *$ & $-0.4278 * * *$ & -0.0542 \\
\hline & $(0.1546)$ & $(0.1522)$ & $(0.1445)$ & $(0.1624)$ & $(0.1653)$ \\
\hline \multirow[t]{2}{*}{ CORPORATE TAX } & $-0.0442 * *$ & $-0.0447 * *$ & $-0.0634 * * *$ & $-0.0828 * * *$ & -0.0301 \\
\hline & $(0.0209)$ & $(0.0202)$ & $(0.0189)$ & $(0.0272)$ & $(0.0263)$ \\
\hline \multirow[t]{2}{*}{ OPENNESS } & 0.0102 & $0.0131 * *$ & 0.0087 & $0.0134 * *$ & 0.0080 \\
\hline & $(0.0063)$ & $(0.0060)$ & $(0.0057)$ & $(0.0056)$ & $(0.0068)$ \\
\hline \multirow[t]{2}{*}{ TRADE BARRIERS } & 0.0150 & 0.0164 & $0.0310 * *$ & -0.0092 & 0.0056 \\
\hline & $(0.0160)$ & $(0.0150)$ & $(0.0139)$ & $(0.0172)$ & $(0.0166)$ \\
\hline \multirow[t]{2}{*}{ DEMOCRACY } & $-0.0594 * *$ & $-0.0798 * * *$ & $-0.1576^{* * *}$ & -0.0187 & $-0.0762 * * *$ \\
\hline & $(0.0243)$ & $(0.0246)$ & $(0.0277)$ & $(0.0198)$ & $(0.0232)$ \\
\hline \multirow[t]{2}{*}{ POLITICAL STABILITY } & 0.0400 & 0.0755 & 0.1223 & -0.0273 & 0.1154 \\
\hline & $(0.0763)$ & $(0.0848)$ & $(0.0754)$ & $(0.0912)$ & $(0.0750)$ \\
\hline \multirow[t]{2}{*}{ CONSTANT } & 3.6181 & $7.6535 * * *$ & $3.0442 *$ & 1.1633 & 3.1442 \\
\hline & $(2.4046)$ & $(2.9494)$ & $(1.7453)$ & (1.6393) & $(2.9674)$ \\
\hline Observations & 115 & 102 & 100 & 83 & 111 \\
\hline$R^{2}$ & 0.9504 & 0.9518 & 0.9159 & 0.7719 & 0.9433 \\
\hline
\end{tabular}

Notes: PCSE and standard errors in parentheses. A common AR(1) correction. ${ }^{*} \mathrm{p}<0.1 ; * *$ $\mathrm{p}<0.05 ; * * * \mathrm{p}<0.01$ 
Table 3. Alternative Estimations of Model 1

\begin{tabular}{llll}
\hline & \multicolumn{1}{c}{ Model 6} & \multicolumn{1}{c}{ Model 7} & \multicolumn{1}{c}{ Model 8} \\
\hline AFFINITY & $0.0472^{* * *}$ & $0.0446^{* * *}$ & $0.0489^{* * *}$ \\
MARKET SIZE & $(0.0102)$ & $(0.0110)$ & $(0.0114)$ \\
& $0.7283^{* * *}$ & $0.7085^{* * *}$ & $0.7308^{* * *}$ \\
LABOR COST & $(0.0904)$ & $(0.1169)$ & $(0.0968)$ \\
CORPORATE TAX & $-0.3231^{* *}$ & -0.2073 & $-0.2862^{*}$ \\
& $(0.1568)$ & $(0.1566)$ & $(0.1594)$ \\
OPENNESS & $-0.0444^{*}$ & $-0.0574 * * *$ & $-0.0620^{* * *}$ \\
TRADE BARRIERS & $(0.0237)$ & $(0.0199)$ & $(0.0183)$ \\
DEMOCRACY & 0.0094 & 0.0097 & 0.0048 \\
& $(0.0066)$ & $(0.0061)$ & $(0.0054)$ \\
POLITICAL STABILITY & 0.0212 & 0.0149 & 0.0223 \\
& $(0.0173)$ & $(0.0181)$ & $(0.0191)$ \\
CONSTANT & $-0.0668^{* *}$ & $-0.0490^{* *}$ & $-0.0905^{* * *}$ \\
& $(0.0335)$ & $(0.0230)$ & $(0.0326)$ \\
Observations & 0.0582 & 0.0189 & 0.0630 \\
$R^{2}$ & $(0.0698)$ & $(0.0789)$ & $(0.0740)$ \\
\hline Notes: Standard & 2.5157 & 2.6642 & 3.0207 \\
& $(2.4449)$ & $(3.0222)$ & $(2.5235)$ \\
& 115 & 115 & 115 \\
& 0.9767 & - & - \\
\hline
\end{tabular}

Notes: Standard errors in parentheses. ${ }^{*} \mathrm{p}<0.1 ; * * \mathrm{p}<0.05 ; * * * \mathrm{p}<0.01$ 